\title{
Device Vibration
}

National Cancer Institute

\section{Source}

National Cancer Institute. Device Vibration. NCI Thesaurus. Code C62806.

Problem associated with the undesirable mechanical oscillation in a device. 